\title{
Cytological and electrophoretic relationships Of some Plantago L. species
}

\author{
Salwa Fahmy Badr \\ Botany Department, Faculty of Science \\ Tanta University, Tanta, Egypt.
}

Badr, S. F. 1999. Relationships of some Plantago species. Taeckholmia 19(1): 27-36. The relationship among 15 samples representing 9 species and 8 sections of Plantago, based on electrophoretic
seed protein profile, as well as karyotype data is discussed in the light of their current sectional and sub sectional
delimitation. The delimitation of $P$. lanceolata as a separate identity from $P$. afra is congruent with the
taxonomic differences between these two species, while its separation from $P$. amplexicaulis and $P$. cylindrica
matches the cytological differences between them. The separation of $P$. alpina and $P$. coronopus based on the
electrophoretic pattern of their seed protein is congruent with the chromosomal differences between them, $P$.
alpina is a tetraploid with $2 \mathrm{n}=24$ and a base number of $X=6$, whereas $P$. coronopus is diploid with $2 \mathrm{n}=10$ and
$X=5$. The delimitation of $P$. afra supports its taxonomic separation from the other studied species. The pattern of
protein electrophoresis under reducing conditions distinguished $P$. major from the remaining species. This
separation is supported by the delimitation of this species in a separate section i.e. Plantago. The separation of $P$.
media from $P$. amplexicaulis and $P$. cylindrica by the analysis of protein pattern, under reducing condition,
confirms their separation based on morphological and chromosomal differences between them. Under non-
reducing condition $P$. amplexicaulis and $P$. cylindrica are separated together as one group distinct from $P$. major
and $P$. media which are delimited as another group.

Key words: Cytology, Electrophoresis, Plantago, Proteins.

\section{Introduction}

Several species of the genus Plantago L. are cultivated for their various medicinal and other economic uses. $P$. lanceolata and $P$. major have been used as external antirheumatic herbal remedies in the traditional medicine (Caniato, 1982). P. lanceolata has been used as an antifertility agent (Herrera et al., 1984). The seeds of P. ovata, P. psyllium and $P$. major are used as a laxatives (Wasicky, 1961). Biologically active polysaccharides have been isolated from P. major (Samuelsen et al., 1995). Plantamajoside, a caffeic acid sugar ester from P. major, possesses antibacterial activity (Ravn and Brimer, 1988). Antitumor activity of phenolic compounds of $P$. asiatica has been demonstrated by Ravn et al. (1990). It is therefore considered of importance to study the species of Plantago.

The genus Plantago L. comprises 250 - 275 species distributed in diverse habitats throughout the World. Pilger (1937) divided the genus into two subgenera Euplantago L. and Psyllium L. Rahn (1978) published a revision of the genus in which he divided it into the three subgenera Plantago L., Coronopus (Lam. \& D.C.) Rahn and Psyllium (Juss). Harms and Reiche.

Cytological investigations of different species of Plantago L. (McCullagh, 1934; Rahn, 1957; Cartier, 1971; Briggs, 1973; Badr, 1980; Badr and El-Kholy, 1987; Badr et al., 1987; Wolff, 1987; Srimanta and Sarmistha, 1997) revealed that this genus has three different basic chromosome numbers of $X=4,5$ and 6. The basic number of $X=6$ is the original number from which $X=5 \& X=4$ have been derived (McCullagh, 1934; Badr and El-kholy, 1987). This number is present in the majority of species, $X=5$ is found in 
several groups particularly of Sect. Leucopsyllium and Sect. Coronopus, whereas $X=4$ is reported in only two species.

Cytological investigations of different species of Plantago L. (McCullagh, 1934; Rahn, 1957; Cartier, 1971; Briggs, 1973; Badr, 1980; Badr and El-Kholy, 1987; Badr et al., 1987; Wolff, 1987; Srimanta and Sarmistha, 1997) revealed that this genus has three different basic chromosome numbers of $X=4,5$ and 6 . The basic number of $X=6$ is the original number from which $X=5 \& X=4$ have been derived (McCullagh, 1934; Badr and El-kholy, 1987). This number is present in the majority of species, $X=5$ is found in several groups particularly of Sect. Leucopsyllium and Sect. Coronopus, whereas $X=4$ is reported in only two species.

Determination of nuclear DNA in root tips of Plantago species. (Badr et al., 1987; Hamoud et al., 1992; Hooglander et al., 1993; Srimanta and Sarmistha, 1997) revealed that DNA amount per basic genome corresponds to the total length of chromosome. It also corresponds with the ploidy level, from diploid to tetraploid to hexaploid, for corresponding basic number (Badr and El-Kholy, 1987; Sarmistha et. al., 1990; Srimanta and Sarmistha, 1997). These results appear to suggest that evolution in Plantago. has probably involved reduction in the nuclear DNA content with the decrease in the number of chromosomes, from $X=6$ to $X=5$ to $X=4$.

Electrophoretic patterns of total seed proteins, as revealed by polyacrylamide gel electrophoresis (PAGE) provide valid evidence for addressing taxonomic and evolutionary problems in plants (Ladizinsky and Hymowitz, 1979; Crawford, 1990). Recently the correlation between SDS-PAGE and chromosomal features and their impact on the interrelationships of some Trifolium (Badr, 1995) and Lathyrus (El-Shanshoury, 1997) taxa showed that the grouping of species in different sections, depending on protein patterns agrees with the previous taxonomy of these species based on morphological and chromosomal criteria.

The present study is undertaken to evaluate the relationships among selected species of Plantago using both cytological and electrophoretic criteria.

\section{Material and Methods:}

This study was carried out on 15 samples representing eight species taxonomically delimited in eight sections under the three subgenera of Plantago. The source and origin of the examined material are given in Table 1. Most species are from Europe, some are from Canada and one is from Egypt. For karyotype analysis, roots taken from pot-grown plants, were pretreated with saturated solution of 1-4 dichlorobenzene for 2-3 h., fixed overnight in 3:1 ethanol glacial acetic acid, and stored in $70 \%$ ethanol at $4{ }^{\circ} \mathrm{C}$. Cytological preparations were made using the Feulgen squash method, and were made permanent by mounting in Euparal. C-metaphase chromosomes were counted and their features, such as somatic number, ploidy level, mean chromosome length (MCL) and mean arm ratio (rvalue) were calculated from photographic prints enlarged to magnification of $4000 \mathrm{x}$ (Hamoud et al.1992).

To extract total seed proteins, $0.1 \mathrm{gm}$ mature seeds were mixed with equal weight of pure, clean, sterile, fine sand and powdered using a mortar and pestle. The powder was homogenized with $1 \mathrm{ml}$ of tris-glycine buffer containing $2 \% \mathrm{NaCl}$ at $\mathrm{pH} 8.2$ for $2 \mathrm{~h}$., by gentle motion. The homogenate was then centrifuged at $12000 \mathrm{rpm}$ for $20 \mathrm{~min}$. at $20^{\circ} \mathrm{C}$. The supernatant (protein extract) was either immediately used for electrophoresis or 
stored at $20^{\circ} \mathrm{C}$ for later use. From this extract $40 \mu \mathrm{l}$ were mixed with equal volume of digestion buffer (tris-borate buffer, $\mathrm{pH}=8$ ), and the mixture was heated for 5 minutes in a boiling water bath. The digestion buffer was used with or without the addition of dithiothreitol (DTE) in order to carry out electrophoresis of seed protein extract under reducing and non-reducing conditions respectively. Three $\mu$ l bromophenol blue were added as tracking dye and $15 \mu \mathrm{l}$ of the mixture were then loaded. In the outside lanes of the gel, $6 \mu \mathrm{l}$ of a marker protein mixture containing 6 different protein subunits with known molecular weight were loaded. Electrophoresis was run in 7.5 - 20 gradient SDS

polyacrylamide gel, $\mathrm{pH}=8$ at $4{ }^{\mathrm{O}} \mathrm{C}$ and $100 \mathrm{v}$ using small gel slabs (Hoefer) for $2 \mathrm{~h}$. Gels were then stained in $2 \%$ solution of Coomassie blue R 250 (Serva) for 30 minutes and destained in a $2: 1(\mathrm{v} / \mathrm{v})$ mixture of methanol and acetic acid for 2 - 3 days.

The banding profile of the 15 examined samples was photographed using Agfa pan film and prints were made using Kodak photographic paper. The number of bands was scored by critical observation of gel records and diagramatic representation of the bands were drawn. The best observations were achieved by placing the gel against white background.

The bands produced by each sample, under reducing and non-reducing conditions, were counted and their relative mobilities compared with those of the standard marker protein. The presence or absence of each band was treated as a binary character in a data matrix (coded 1 and 0 respectively) for computation using the program NTSYS pc (numerical taxonomy and multivariate analysis system; Rohlf, 1988). Quantitative variation expressed as difference in intensity and thickness of bands, was also observed, but since this type of variation is often associated with the genotype, it was not taken into consideration when coding for the numerical analysis. The method applied is based on cluster analysis and expresses the relationships of the studied taxa as percent similarity in dendrogram. The bands scored from electropherograms produced under reducing and nonreducing conditions were used as two different sets of data for computer analysis, to produce two separate classifications. A combination of the two sets of data was used for a third classification based on the total number of bands. For the numerical analysis, the samples were numbered as in Table 1 . 
Relationships of some Plantago species

Received 13 January 1999. Revision accepted 7 April 1999

$-30-$ 
Relationships of some Plantago species

\section{Results}

Electropherograms of the examined 15 samples revealed a number of bands ranging from 2 to 7 in $P$. media (1) and P. coronpus (1) respectively, under reducing conditions (Fig. 1. a) and ranging from 4 bands in $P$. afra to 11 bands in $P$. lancoelata and $P$. amplexicaulis under non-reducing conditions( Fig . 1. b).

The relationships among samples based on the variation in the banding profile under non-reducing condition using the NTSYS program are shown by the dendrogram given in( Fig. 2.a).The studied samples have an average taxonomic distance of about 1.9. At this level the two samples of P. lanceolata $(12 \& 13)$ are separated from the rest of species. At a taxonomic distance level of 1.5 the two species of $P$. coronopus $(8 \& 9)$ are also delimited from the remaining species. The remaining species are divided into two groups at a taxonomic distance of 1.3. One of these groups includes P. amplexicaulis (14) and $P$. cylindrica (15) and the other one includes the rest of the species. The four samples of $P$. media $(4,5,6 \& 7)$ are separated from the other species at taxonomic distance of 1.2. Within the $P$. media, the samples collected from the same country clustered together. $P$. alpina (10) and $P$. afra (11), which are included under two separate subgenera of the genus, were delimited at low taxonomic distance between them. $P$. major represented by 3 samples $(1,2 \& 3)$, have a low degree of taxonomic distance at 0.6 , sample 3 was separated from samples 1 and 2, which showed identical banding profile.

Dendrogram patterns under reducing conditions (Fig. 2.b) revealed that the isolation of most species was similar to that produced under non-reducing conditions. However, some species revealed a change in dendrogram pattern under reducing condition. The two samples of $P$. coronopus ( $8 \& 9)$ are separated from each other at taxonomic distance of 0.8 , despite their grouping under reducing condition at $100 \%$ similarities. $P$. media is represented by 4 samples $(4,5,6 \& 7)$ collected from different countries. Reducing pattern of $P$. media seed protein separated sample 6 from the other samples at a taxonomic distance 0.5 . This sample was clustered with sample 5 under nonreducing conditions. The dendrogram based on combining the two sets of data i.e. reducing and non-reducing condition revealed the same patterns as produced under reducing conditions for all samples (Fig. 2.b). 
Relationships of some Plantago species

Fig. 1(A): Examples of electropherograms produced by SDS-PAGE analysis of seed proteins of Plantago L. samples numbered as in Table 1.

$\mathrm{A}=$ under reducing conditions
$\mathrm{B}=$ undre non-reducing conditions

$\mathrm{M}=$ Marker protein standard

Received 13 January 1999. Revision accepted 7 April 1999.

$-32-$ 


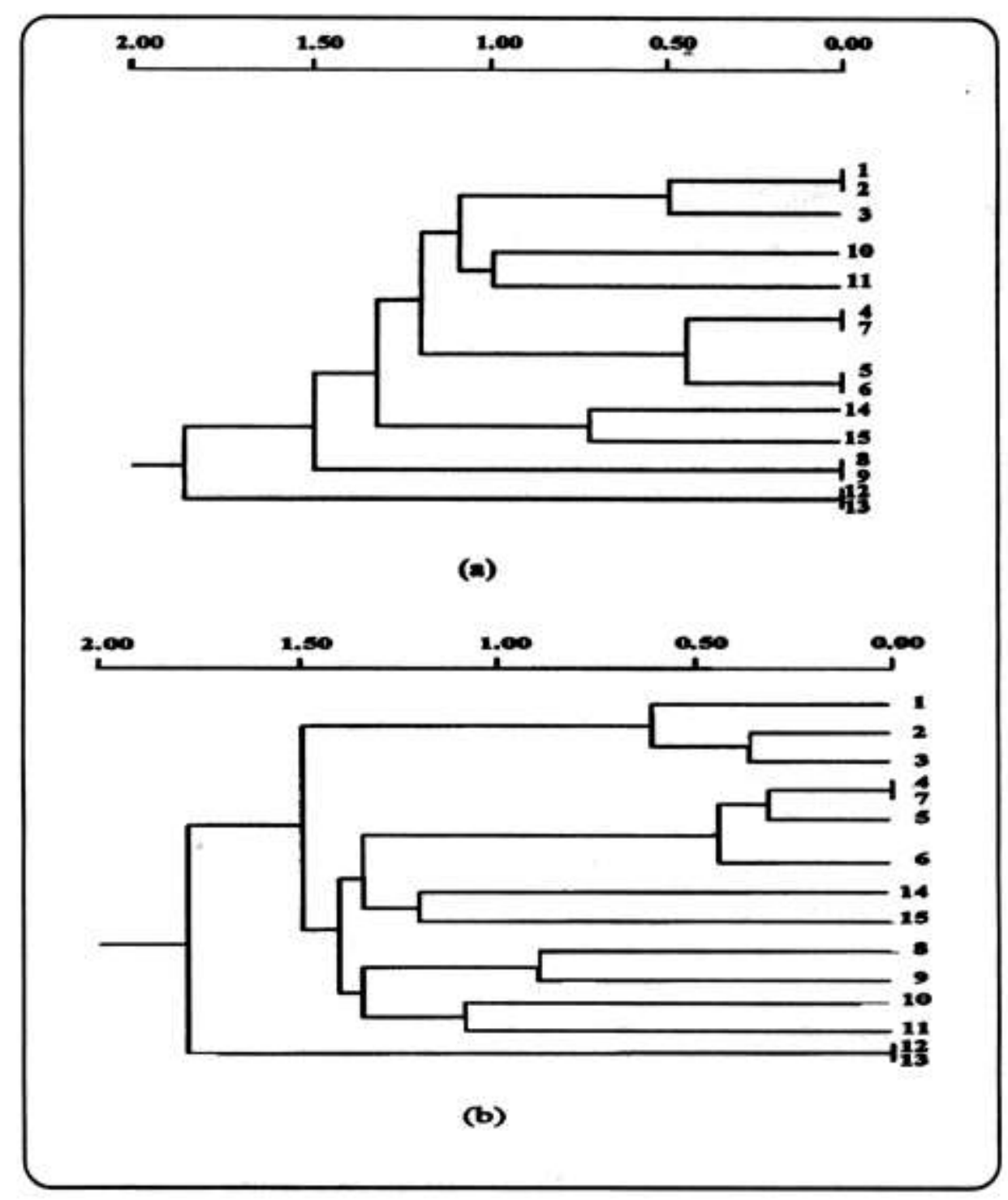

Fig. 2 (a, b): Dendograms illustrating the relationship among the 15 studied samples of Plantago L. produced by analysis of variation in SDS-PAGE of seed proteins samples are numbered as in Table 1.

$\mathrm{a}=$ Under reducing conditions

$\mathrm{b}=$ Undre reducing conditions and combination of reducing and non-reducing conditions 


\section{Discussion:}

The chromosomal features of the examined samples are summarized in Table 1. The diploid chromosome number of $2 \mathrm{n}=12(X=6)$ is recorded in three species, $P$. major $(1$, $2 \& 3), P$. afra (11) and P. lanceolata (12\& 13). A tetraploid chromosome number of $2 \mathrm{n}$ $=24(x=6)$ was observed in the four samples of $P$. media $(4,5,6 \& 7)$ and in P. alpina (10). A diploid chromosome number of $2 \mathrm{n}=10(X=5)$ is recorded in the two samples of $P$. coronopus ( $8 \&$ 9), in P. amplexicaulis (14) and P. cylindrica Forssk (15).

The phenetic relationships between the studied samples as expressed by the numerical analysis of their seed protein profiles, under reducing and non-reducing conditions, clearly demonstrated the delimitation of P. lanceolata (12 \& 13) from the rest of the studied samples. This species has been placed in sect. Arnoglossum (Decne) in subg. Euplantago by Pilger (1937) and in sect. Lanceifolia of subg. Psyllium by Rahn (1978). Among the studied species in subg. Psyllium sensu Rahn only P. lanceolata and $P$. afra have $X=6$, whereas the species, $P$. amplexicaulis and $P$. cylindrica have $X=5$. Subg. Psyllium sensu Pilger only comprises $P$. afra. The delimitation of $P$. lanceolata as a separate identity in this study from $P$. afra is congruent with the taxonomic differences between these two species, while, its separation from $P$. amplexicaulis and $P$. cylindrica matches the cytological differences between them. In these analyses $P$. alpina (10) and the two samples of $P$. coronpus ( $8 \& 9$ ) are separated from each other contradicting the close relationship between these two species as proposed by both Pilger ( 1937) who grouped them in sect. coronopus of subg. Euplantago and Rahn (1978) who delimited them in subg. Coronopus. However, the separation of $P$. alpina and $P$. coronopus based on the electrophoretic pattern of their seed protein is congruent with the chromosomal differences between them, $P$. alpina is a tetraploid with $2 \mathrm{n}=24$ and a base number of $X=$ 6, whereas $P$. coronopus is diploid with $2 \mathrm{n}=10$ and $X=5$ (Badr, 1992).

$P$. afra is distinguished by its protein pattern under both reducing and nonreducing conditions. The delimitation of this species in the present study supports its taxonomic separation from the other studied species by Pilger (1937). Meanwhile, Rahn (1978) placed P. afra in subg. Psyllium with other three of the studied taxa, but in a separate section i.e. Psyllium. The pattern of protein electrophoresis under reducing condition clearly distinguished the samples of $P$. major (1, $2 \& 3$ ) from the remaining species. This separation is supported by the delimitation of this species in separate section i.e. Plantago of subg. Plantago by Rahn (1978). The variation in chromosome length and the high difference in DNA amounts recorded by Badr (1992) confirm the distant situation of $P$. major. The separation of samples of $P$. media $(4,5,6 \& 7)$ in a separate group from $P$. amplexicaulis (14) and $P$. cylindrica (15) by the analysis of protein pattern under reducing condition confirms their separation based on morphological characters as proposed by both Pilger (1937) and Rahn (1978), and is matched by chromosomal differences between them (Badr and El-Kholy, 1987; Badr, 1992). Under non-reducing condition $P$. amplexicaulis (14) and $P$. cylindrica (15) are separated together as one group distinct from $P$. major (1,2 \& 3) and $P$. media (4, 5, $6 \&$ 7), which are delimited as another group. These two species are placed together in subg. Plantago by Rahn (1973) and in two separate sections in subg. Euplantago by Pilger (1937).

Further investigation involving more taxa, by protein electrophoresis and other molecular approches, may enable us to reach more satisfactory sectional delimitation and species assignment of species in the genus Plantago. 
Relationships of some Plantago species

\section{Acknowledgement:}

The author is most grateful to Prof. Dr. ABD El-FATTAH BADR for his assistance with the technical part and his help in preparing the manuscript.

\section{References:}

Badr, A. 1980. Chromosome counts of six Egyptian plants. Egypt. J. Bot., 23: 127 - 129.

Badr, A. 1995. Electrophoretic studies of seed proteins in relation to chromosomal criteria and the relationships of some taxa of Trifolium. Taxon. 44:183-191.

Badr, A. \& El-Kholy, M.A. 1987. Chromosomal studies in the Egyptian flora II. Karyotype studies in the genus Plantago L. Cytologia 52 : 1-3.

Badr, A.; Labani, R. \& Elkington, T.T. 1987. Nuclear DNA variation in relation to cytological features of some species in the genus Plantago L. Cytologia, 52: 1-5.

Badr, S. 1992. Cytological studies in the genus Plantago L. (Plantaginaceae) Ph.D. thesis, Tanta University.

Briggs, B.D. 1973. Chromosomal studies on Plantago in Australia. Contrib, New Wales, Nation. Herb. 4: 399 - 405.

Caniato, R. 1982. External antirheumatic and antineuralgic herbal remedies in the traditional medicine of north eastern Italy. J. Ethnopharm. 6: 161-190.

Cartier, D. 1971. Etude biosystematique de quelques especes du genera Plantago (Tourn.) L. (Sections Coronopus DC. et oreades (Decne) I. Historique, races chromosmiques du Plantago alpina L. et du Plantago serpentina All. Rev. Gen. Bot. 78 : 493 - 556.

Crawford, D. J. 1990. Plant molecular systematics, Macromolecular approaches. John Wiley \& Sons. New York.

El-Shanshoury, A.R. 1997. The use of seed proteins revealed by SDS PAGE in taxonomy and Phylogeny of some Lathyrus species. Biologia Plantarum 39: 553-559.

Hamoud, M.A.; Badr, A.; Badr, S. \& El-kington, T.T. 1992. Variation in 4 C DNA content as related to cytological features of some species of Plantago $L$. Taeckholmia 14: 79 - 92.

Herrera, C.L.; Ramos, E.V.\& Villanueva, B.A. (1984). Philippine plants as possible sources of antifertility agents. Philippine J. Sci. 113: 91 - 129.

Hooglander, N.; Lumaret-R; \& Bos-M. 1993. Inter-intraspecific variation of chloroplast DNA of European Plantago L. spp. Heredity 70: 3, 322 - 334.

Ladizinsky, G. \& Hymowitz, T. 1979. Seed protein electrophoresis in taxonomic and evolutionary studies. Theor. appl. Genet. 54 : 145-151.

McCullagh, D.D. 1934. Chromosome and chromosome morphology in Plantaginaceae (1) Genetica, 16: 1 - 44.

Pilger, R. 1937. Plantagniaceae. In Engler and Diels. Das pflanzereich vol. 4 w. Engelman Leipzig.

Rahn, K. 1957. Chromosome numbers in Plantago L. Saertryk Af Botanisk Tidsskr. Bot.Tidsskr, 53: 369 - 378.

Rahn, K. 1978. Nomenclatural changes within the genus Plantago L. infraspecific taxa and subdivisions of the genus. Bot. Tidssk. 73: $106-111$.

Ravn, H. \& Brimer, L. 1988. Structure and antibacterial activity of Plantamajoside, acaffeic acid sugar ester from Plantago major subsp. major. Phytochemistry, 27: 3433 - 3437. 
Ravn, H.; Nishibe, S.; Sashara, M. \& Lixuebo. 1990. Phenolic compounds from Plantaog asiatica, Phytochemistry 29: 3627 - 3631.

Rohlf, F.J. 1988. NTSYS-PC-numerical taxonomy and multivariate analysis. New York.

Samuelsen, A.B.; Paulsen, B.S.; Wold, J.K.; Otsuka, H.; Yamada, H. \& Espevik, T. 1995. Isolation and partial characterization of biologically active Polysaccharides from Plantago major L. Phytotherapy Res. 9: 211 - 218.

Sarmistha; Sharma-AK \& Sen-S 1990. Chromosome complements, Nuclear DNA and genetic distance as measures of interrelationship in Plantago L. Nucleus-Calcutta 33: 1 - 2 .

Srimanta, P. \& Sarmistha, S.R. 1997. DNA Content, chromosome composition, and isozyme patterns in Plantago L. The Botanical Review. 63 : 124 - 139.

Wasicky, R. 1961. Investigations of the seeds of Plantago ovata, P. psyllium and P. major variety cruneta as laxatives. $\mathrm{Pl}$. Med. 9: 232 - 244.

Wolff, K. 1987. Genetic analysis of ecological relevant morphological variability in Plantago lanceolata L. II. Localization and organization of quantitative trait loci. Theor. Appl. Genet. 73: 903 - 914. 


\begin{tabular}{|c|c|c|c|c|c|c|c|}
\hline No. & Plantago species & Sources or origin & $2 n$ & $\mathrm{x}$ & $\begin{array}{c}\text { Ploidy } \\
\text { level }\end{array}$ & MCL & $\mathrm{r}$-values \\
\hline I & $\begin{array}{r}\text { Subgenus : Plantago } L . \\
\text { Section : Plantago } L . \\
\text { P. major L. ssp. major }(1)\end{array}$ & & & & & & \\
\hline $\begin{array}{l}1 \\
2\end{array}$ & P. major L. ssp. major (2) & Sheffield. United Kingdom & 12 & 6 & $2 \mathrm{x}$ & $1.68+0.03$ & $1.3+0.07$ \\
\hline 3 & P. major L. ssp. intermedia (3) & Alberta, Canada & 12 & 6 & $2 \mathrm{x}$ & $1.51+0.02$ & $1.32+0.11$ \\
\hline & $\begin{array}{r}\text { Section : Lamprosntha } \\
\text { (Decne) } \\
\text { P. major }(1) \\
\text { P. major }(2)\end{array}$ & Wageningen, Netherland & 12 & 6 & $2 \mathrm{x}$ & $2.32+0.04$ & $1.97+0.12$ \\
\hline $\begin{array}{l}4 \\
5\end{array}$ & P. major (3) & Debyshire, United Kingdom & 24 & 6 & $4 \mathrm{x}$ & $3.24+0.05$ & $1.57+0.06$ \\
\hline$\frac{3}{6}$ & P. major (4) & Gottingen, University, Germany & 24 & 6 & $4 \mathrm{x}$ & $2.86+0.07$ & $1.52+0.08$ \\
\hline 0 & & Leipzing, Germany & 24 & 6 & $4 \mathrm{x}$ & $2.85+0.08$ & $1.63+0.07$ \\
\hline 1 & & Dorset, United Kingdom & 24 & 6 & $4 \mathrm{x}$ & $2.90+0.08$ & $1.59+0.08$ \\
\hline II & $\begin{array}{l}\text { Subgenus : Coronopus (Lam \& D.C.) } \\
\text { Section: Coronopus (Lam \& D.C.) }\end{array}$ & & & & & & \\
\hline 8 & P. coronopus L. (1) & & & & & & \\
\hline 9 & $\begin{array}{r}\text { P. coronopus L. (2) } \\
\text { Section: Maritima (Rahn Sect. Nov.) }\end{array}$ & $\begin{array}{r}\text { Gottingen University, Germany } \\
\text { Dorset, United Kingdom }\end{array}$ & $\begin{array}{c}10+0-B \\
10\end{array}$ & $\begin{array}{l}5 \\
5\end{array}$ & $\begin{array}{l}2 \mathrm{x} \\
2 \mathrm{x}\end{array}$ & $\begin{array}{l}2.75+0.20 \\
2.04+0.15\end{array}$ & $\begin{array}{l}1.23+0.08 \\
1.43+0.11\end{array}$ \\
\hline & P. alpina $\mathrm{L}$. & 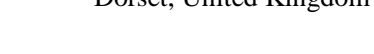 & & & & $2.04+10.13$ & \\
\hline 10 & & Gottingen University, Germany & $24+\mathrm{B}$ & 6 & $4 \mathrm{x}$ & $2.22+0.08$ & 1.93 \\
\hline III & $\begin{array}{l}\text { Subgenus : Psyllium (Juss, Harms \& Heiche) } \\
\text { Section : Psyllium (Juss) (Lam \& D.C) }\end{array}$ & & & & & & \\
\hline 11 & $\begin{array}{r}\text { P. afrea } \mathrm{L} . \\
\text { Section : Lanceifolia }(\text { Bern }) \\
\text { P. lancealata L. (1) }\end{array}$ & Gottingen University, Germany & 12 & 6 & $2 \mathrm{x}$ & $2.92+0.06$ & $1.41+0.07$ \\
\hline 12 & $\begin{array}{r}\text { P. lancealata L. (2) } \\
\text { Section } \text {. }\end{array}$ & Sheffield, United Kingdom & 12 & 6 & $2 \mathrm{x}$ & $2.65+0.1$ & $3.22+0.92$ \\
\hline 13 & $\begin{array}{l}\text { Section : Bauphula (Decne) } \\
\text { P. amplexicaulis Cav. }\end{array}$ & Ontario, Canada & 12 & 6 & $2 \mathrm{x}$ & $2.55+0.09$ & $2.35+0.56$ \\
\hline 14 & $\begin{array}{r}\text { Section : Albicans (Bar.) } \\
\text { Series : Albicantes (Rhn. Ser. Nov.) } \\
\text { P. cylindrica Forssk. }\end{array}$ & Gottingen University, Germany & 10 & 5 & $2 \mathrm{x}$ & $3.39+0.06$ & $2.2+1.96$ \\
\hline 15 & & South Sinai, Egypt & 10 & 5 & $2 \mathrm{x}$ & $2.38+0.02$ & $1.55+0.14$ \\
\hline
\end{tabular}

Table 1: A survey of the Plantago samples studied and of their chromosomal features. MCL = mean chromosome length $(\mathrm{m}) ; \mathrm{r}$-value $=$ mean chromosome arm ratio. 